\section{Overseas investors plan six 'world class' universities in India}

\section{K. S. Jayaraman, New Delhi}

Wealthy Indian entrepreneurs based in New York are planning to invest up to $\$ 1$ billion to establish six "world class" private research universities across India.

Although similar proposals have been resisted in the past as a potential threat to existing institutions, the new plan has been endorsed by Prime Minister Atal Behari Vajpayee. "We will actively facilitate this and other similar initiatives," he told the 88th Indian Science Congress in New Delhi last week.

The backers of the proposed Global Institutes of Science and Technology (GIST) say that "the need for science and technology talent will continue to rise in India as well as globally, and that India will be a major contributor of that talent".

GIST will be privately funded and managed with no financial input from India's government. It will be registered as an Indian company and, the backers say, will have a president accountable to a governing board made up of major sponsors, world-renowned scientists and chief executive officers of multinational corporations.

Each of its six campuses will have a yearly input of 2,000 students, and GIST plans to form affiliations with leading US research universities.

The proposal was approved last November by the prime minister's science advisory committee, but it has yet to be formally cleared by India's Ministry of Human Resources Development.

Vajpayee also said his government would double research funding by 2004, reform the structure of highereducational institutions, and free scientific institutions from bureaucratic control. In return, he asked the scientists to transform India into a leading scientific nation in the twenty-first century.

| http://isc2001.nic.in/vsisc2001

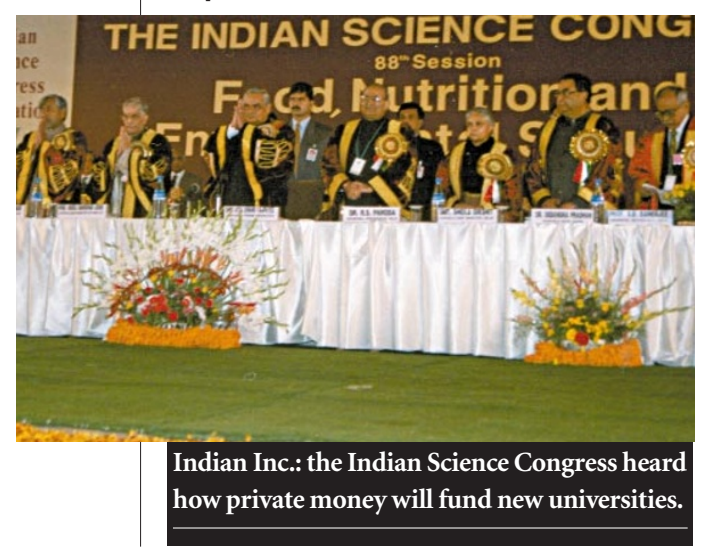

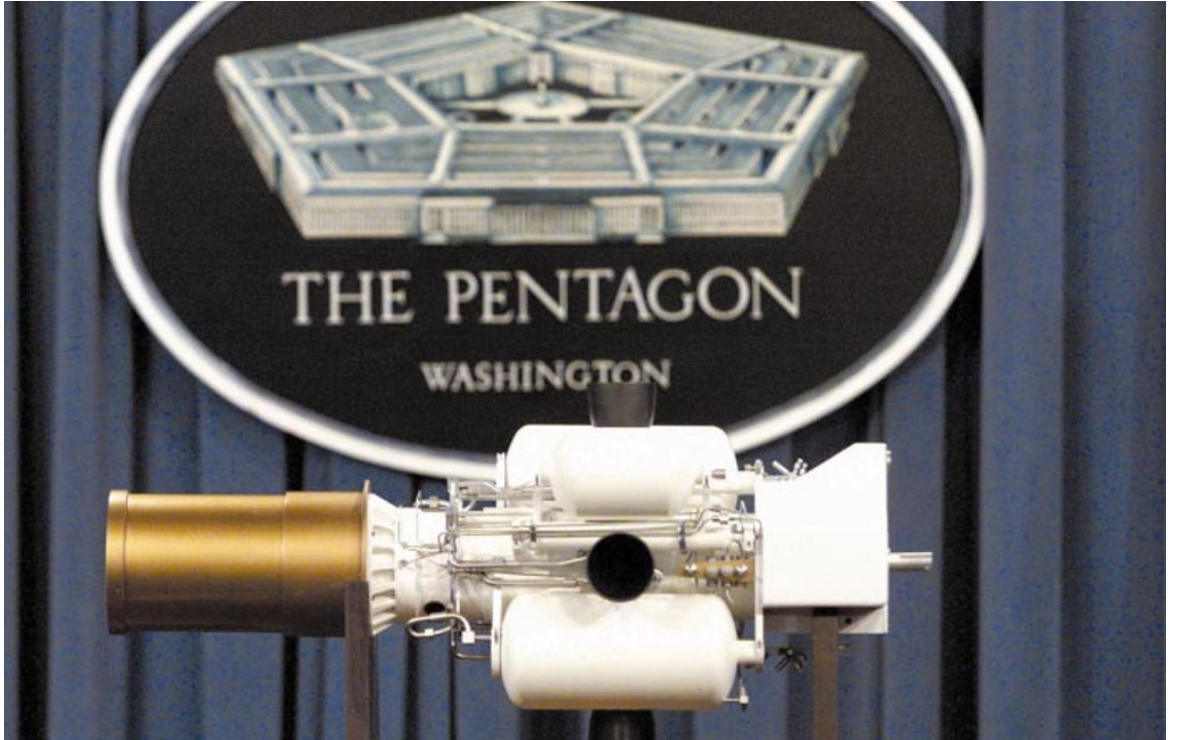

In for the kill: a model 'kill device' from the missile defence system tested by the Pentagon last year.

\title{
Bush targets space-based missile defence system
}

\section{Irwin Goodwin, Washington}

George W. Bush's choice of defence secretary shows that his new administration aims to give the United States a missile defence shield - confirming the fears of some scientists and of US allies.

But some scientific groups say that Bush's choice of Donald Rumsfeld for the position could also herald a push by the United States to establish military supremacy in space.

Rumsfeld is a champion not only of missile defence, but also of US efforts to control space by developing the technology to protect satellites in orbit. Such initiatives could militarize space in the next two decades, a prospect that some defence experts havelong urged and others have passionately opposed.

Rumsfeld, who was President Gerald Ford's White House chief of staff and then secretary of defence 25 years ago, chaired a bipartisan commission for Congress in 1998 that helped to build political support for missile defence by warning that Iran, Iraq and North Korea were closer than had been thought to being able to direct nuclear or biological warheads at the United States.

Now, another congressionally mandated commission headed by Rumsfeld is completing a report on the threats to US satellites, which are increasingly vital to military and civilian communications. The report, expected this month, will endorse "US control of space, including defending our own satellites and engaging those of any enemy," according to one member of the panel.

One sceptic is space-policy analyst John Pike, formerly at the Federation of American Scientists and now at Globalsecurity.org.
Pike says that members of Congress pushed for the satellite study because they believe the United States should devise anti-satellite weapons and consider establishing a space force as an arm of the Defense Department. He opposes the idea, arguing that it is "singularly misguided, when we are the only nation with satellites worth shooting at".

The National Missile Defense (NMD) planned by President Bill Clinton would have been land-based, with interceptor missiles ready for launching from Alaska by 2007. It calls for satellites that would track missiles carrying weapons of mass destruction.

Bush's defence system, by contrast, would use space weaponry. His vision is reminiscent, some observers say, of President Ronald Reagan's 1983 dream of an impenetrable Strategic Defense Initiative, dubbed Star Wars. Although the Pentagon has been working for years on lasers that might someday be mounted on aircraft or satellites, such weapons do not yet exist.

Clinton's proposed NMD is already undergoing painful reappraisal, after two out of three early tests failed. But the Pentagon still plans to attempt at least three missile interceptions this year, and then proceed until 21 tests have been successful.

The Union of Concerned Scientists and the Security Studies Program at the Massachusetts Institute of Technology have concluded that nations that could launch missiles at the United States could also develop countermeasures to defeat a limited defence system. The Cornell University physicist Hans Bethe gave Congress the same advice more than 30 years ago. 